\title{
Differences at the Surface Roughness by the ELID and Grinding Technology
}

\author{
Martin Novak ${ }^{1}$, Hiroshi Kasuga ${ }^{2}$, Hitoshi Ohmori ${ }^{2}$ \\ ${ }^{1}$ Faculty of Production Technology and Management, J. E. Purkyne University in Usti nad Labem. Czech Republic. \\ Europe.novak@fvtm.ujep.cz \\ ${ }^{2}$ Materials Fabrication Laboratory, RIKEN, Wako-shi, Tokyo, Japan. h-kasuga@ riken.jp; ohmori@mfl.ne.jp
}

This paper deals with surface roughness and surface profile in high precision methods of materials finishing. One of them is ELID grinding process and the second method is fine grinding. There is surface profile and roughness compared of the three materials samples - carbide steel and two aluminium alloys. In the paper are shown the principle of the ELID grinding and fine grinding, results of surface measurement between ELID and ground surface. Both methods are very precision in the focus on surface roughness - measured units in nano scale. The paper shows also real topology of the surfaces and visible tool marks especially by the fine grinding method. Next we can see new possibilities in finishing methods for different areas of the production, automotive, aerospace, medicine and cosmic industry.

Keywords: ELID, Fine Grinding, Roughness, Tool Marks, Surface profile

\section{Acknowledgement}

Above mentioned results were created by means of the project in J. E. Purkyne University in Usti nad Labem "Materials and Human Resources for Environment".

\section{CZ.1.07/2.3.00/30.0028}

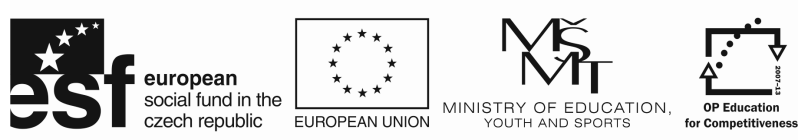

INVESTMENTS IN EDUCATION DEVELOPMENT

\section{References}

[1] KOCMAN, K. 2010. Analyza vyvojovych brousicich kotoucu na bazi mikrokrystalickeho korundu, Strojirenska technologie, vol. XV, no. 3, UJEP, Usti nad Labem, 40-47 pp.

[2] LUKOVICS, I., BILEK, O., HOLEMY, S. 2010. Development of Grinding Wheels for Tools Manufacturing, Manufacturing Technology, vol. 10, no. 10, UJEP, Usti nad Labem, 10-16 pp.

[3] MARINESCU, I., D., et all. 2007. Handbook of Machining with Grinding wheels, Boca Raton: CRC Press, 592 pp.

[4] NOVAK, M. 2011. Surface quality of hardened steels after grinding. Manufacturing Technology, vol. 11, no. 11, UJEP, Usti nad Labem, 55-59 pp.

[5] KUNDRAK, J. 2011. Alternative machining procedures of hardened steels, Manufacturing Technology, vol. 11, no. 11, UJEP, Usti nad Labem, 32-39 pp.

[6] NOVAK M., LATTNER M., RUZICKA L., HOLESOVSKY F., 2010. Grinding and surface quality parameters at automotive parts machining, Manufacturing Technology, vol. 10, no. 10, UJEP, Usti nad Labem, $36-38$ pp.

[7] HOLESOVSKY, F., NOVAK, M. 2010. Grinding and its influence to ground surface durability. Proceedings of International Conference on Advances in Materials and Processing Technologies, Paris. Publisher: Amer INST Physics, Melville, NY, USA. ISBN 978-0-7354-0871-5. WOS: 000287169300158.

[8] NOVAK, M. 2012. Influence of the Corrosion Surrounding on Surface Quality of Ground Hardened Steels In Key Engineering Materials, vol. 496: Precision Machining IV. TTP, Zurich, 25 - 30 pp., WOS:000302674400005

[9] NOVAK, M., NAPRSTKOVA, N., RUZICKA. L. 2012. New ways in aluminium alloys grinding. In Key Engineering Materials, vol. 496: Precision Machining IV. TTP, Zurich, 132 - 137 pp. WOS:000302674400023

[10] BRINKSMEIER, E., MUTLUGÜNES, Y., KLOCKE, F., AURICH, J.C., SHORE, P. \& OHMORI, H. 2010, "Ultra-precision grinding", CIRP Annals - Manufacturing Technology, vol. 59, no. 2, pp. 652-671.

[11] INADA, A., MIN, S. \& OHMORI, H. 2011, "Micro cutting of ferrous materials using diamond tool under ionized coolant with carbon particles", CIRP Annals - Manufacturing Technology, vol. 60, no. 1, pp. 97-100. 
[12] LEE, H., KASUGA, H., OHMORI, H., LEE, H. \& JEONG, H. 2011, "Application of electrolytic in-process dressing (ELID) grinding and chemical mechanical polishing (CMP) process for emerging hardbrittle materials used in light-emitting diodes", Journal of Crystal Growth, vol. 326, no. 1, pp. 140-146.

[13] MADL, J. 2012. Surface Properties in Precise and Hard Machining, Manufacturing Technology, vol. 12, no. 13, 158-166 pp.

[14] NOVAK-MARCINCIN, J. TOROK, J. BARNA, J., NOVAKOVA-MARCINCINOVA, L. 2012. Technology of Perspective Scanning Methods for Realization of 3D Models of Manufacturing Devices, Manufacturing Technology, vol. 12, no. 13, 186-191 pp.

[15] VALASEK, P., MULLER, M. 2012. Influence of bonded abrasive particles size on wear of polymeric particle composites based on waste, Manufacturing Technology, vol. 12, no. 13, 268-272 pp.

[16] MICHNA, S., NAPRSTKOVA, N. 2012. Research into the causes cracking of aluminum alloys of $\mathrm{Al}-\mathrm{Cu}$ during mechanical machining, Manufacturing Technology, vol. 12, no. 12, 47-51 pp.

[17] KUSMIERCZAK, S., NAPRSTKOVA, N., SVOBODOVA, J. 2012. 2012. Evaluation of sheet degradation with surface treatment, Engineering for Rural Development, vol. 11, 32-36 pp.

[18] VARGA, G., KUNDRÁK, J. 2013. Effect of environmentally conscious machining on machined surface quality, Applied Mechanics and Materials 309, pp. 35-42

[19] KUNDRAK, J., VARGA, G., DESZPOTH, I., MOLNAR, V. 2013. Some aspects of the hard machining of bore holes, Applied Mechanics and Materials 309, pp. 126-132.

[20] VASILKO, K., MACUROVA, A. 2012. Two Locals Extremes of Cutting Speed. Manufacturing Technology, vol. 12, no. $12,86-89$ pp.

Copyright () 2013 Published by Manufacturing Technology. All rights reserved

Paper number: M201340

Manuscript of the paper received in 2013-01-07. The reviewer of this paper: Karol Vasilko. 